\title{
LA-UR-19-28208
}

Approved for public release; distribution is unlimited.

Title: $\quad$ Metal Chlorination, Coalescence, and Direct Oxide Reduction Progress Report: July 2019

Author(s): $\quad$ Parkinson, David Allen

Intended for: Report

Issued: 
Disclaimer:

Los Alamos National Laboratory, an affirmative action/equal opportunity employer, is operated by Triad National Security, LLC for the National Nuclear Security Administration of U.S. Department of Energy under contract 89233218CNA000001. By approving this article, the publisher recognizes that the U.S. Government retains nonexclusive, royalty-free license to publish or reproduce the published form of this contribution, or to allow others to do so, for U.S. Government purposes. Los Alamos National Laboratory requests that the publisher identify this article as work performed under the auspices of the U.S. Department of Energy. Los Alamos National Laboratory strongly supports academic freedom and a researcher's right to publish; as an institution, however, the Laboratory does not endorse the viewpoint of a publication or guarantee its technical correctness. 


\section{Metal Chlorination, Coalescence, and Direct Oxide Reduction Progress Report July 2019}

David Parkinson

12 July 2019

- Los Alamos 


\section{Report Overview}

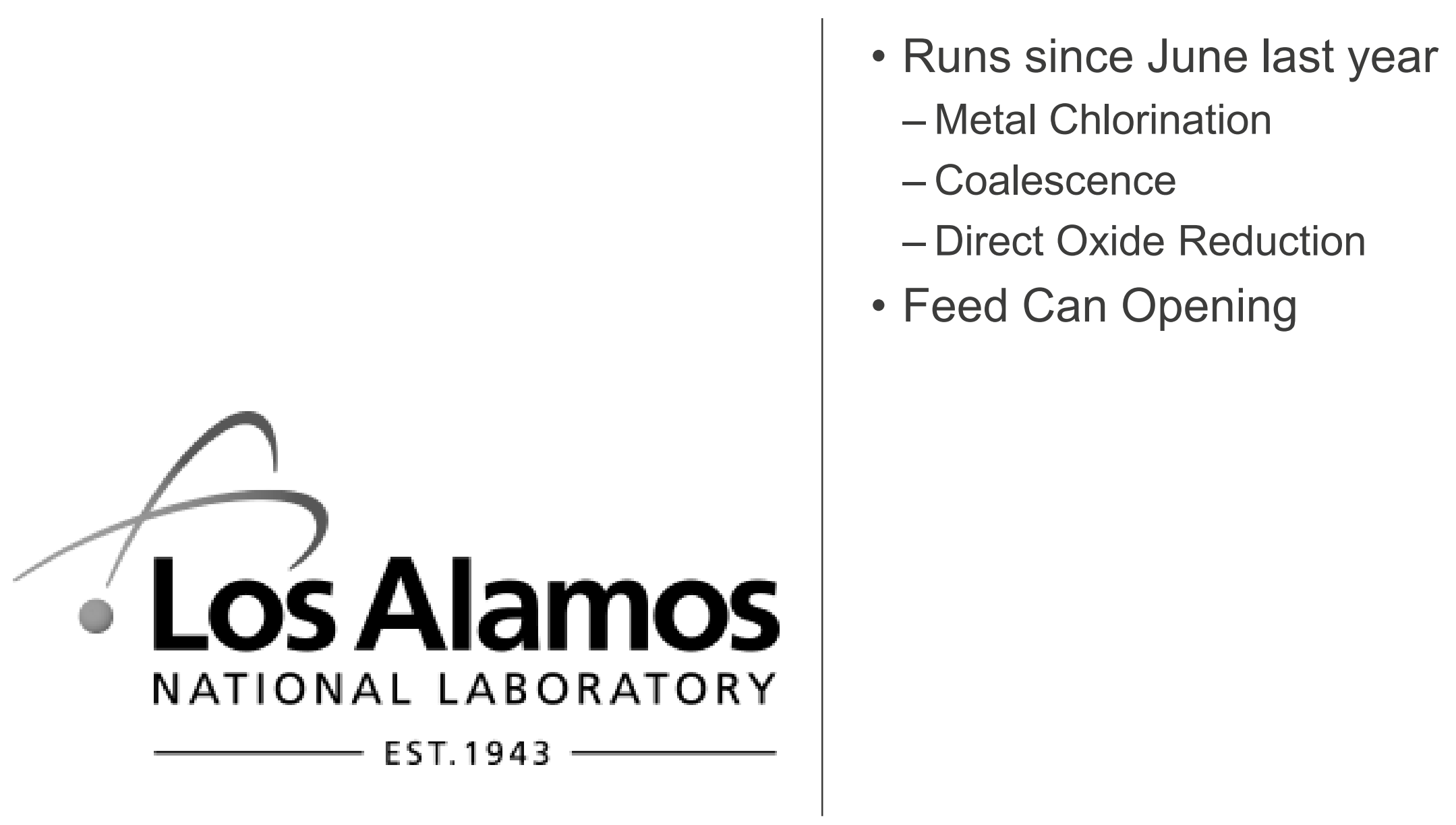




\section{Metal Chlorination (MC)}

- Only Molten Salt Extraction has been run. Chlorine system down.

- In December 1 run left under vacuum and oxidized producing much $76 \%$ yield and criticality safety issues

- In January and February there was 1 failed run each month from stirrer issues not allowing stirring

\begin{tabular}{|l|c|c|c|}
\hline Month & $\begin{array}{c}\text { Successful } \\
\text { Runs }\end{array}$ & Pu out (kg) & $\begin{array}{c}\text { Average } \\
\text { Yield (\%) }\end{array}$ \\
\hline Aug-18 & 3 & 11.64 & 97.5 \\
\hline Nov-18 & 3 & 11.41 & 97.7 \\
\hline Dec-18 & 3 & 10.63 & 90.8 \\
\hline Jan-19 & 3 & 12.13 & 97.4 \\
\hline Feb-19 & 4 & 15.24 & 97.6 \\
\hline Mar-19 & 2 & 7.58 & 95.9 \\
\hline Apr-19 & 1 & 3.61 & 93.0 \\
\hline May-19 & 1 & 2.68 & 98.4 \\
\hline Jun-19 & 3 & 10.73 & 97.4 \\
\hline Totals & $\mathbf{2 3}$ & $\mathbf{8 5 . 6 5}$ & $\mathbf{9 6 . 2 ~ ( A v g ) ~}$ \\
\hline
\end{tabular}




\section{Coalescence (COL)}

Successful

Month

Aug-18

Nov-18

Feb-19

Mar-19

Apr-19

May-19

Totals Runs

2

1

4

2

1

1

11
Average

Pu out (kg) Yield (\%)

92.1

91.5

72.7

89.7

62.8

73.0

$34.68 \quad 80.3($ Avg) 


\section{Total Feed to Electrorefining (ER) by Month}

\begin{tabular}{|c|c|c|c|c|c|c|}
\hline Month & MC Runs & $\begin{array}{l}\text { MC Pu out } \\
(\mathbf{k g})\end{array}$ & COL Runs & $\begin{array}{c}\text { COL Put } \\
\text { oug) }\end{array}$ & $\begin{array}{c}\text { Total } \\
\text { Runs }\end{array}$ & Total \\
\hline Aug-18 & 3 & 11.64 & 2 & 7.48 & 5 & 19.11 \\
\hline Nov-18 & 3 & 11.41 & 1 & 3.53 & 4 & 14.94 \\
\hline Dec-18 & 3 & 10.63 & 0 & 0 & 3 & 10.63 \\
\hline Jan-19 & 3 & 12.13 & 0 & 0 & 3 & 12.13 \\
\hline Feb-19 & 4 & 15.24 & 4 & 11.24 & 8 & 26.48 \\
\hline Mar-19 & 2 & 7.58 & 2 & 7.10 & 5 & 14.67 \\
\hline Apr-19 & 1 & 3.61 & 1 & 2.71 & 2 & 6.32 \\
\hline May-19 & 1 & 2.68 & 1 & 2.63 & 2 & 5.31 \\
\hline Jun-19 & 3 & 10.73 & 0 & 0 & 3 & 10.73 \\
\hline Totals & 23 & 85.65 & 11 & 34.68 & 34 & 120.33 \\
\hline
\end{tabular}




\section{Direct Oxide Reduction (DOR) Progress}

- Refilled scrubber with $\mathrm{NaOH}$

- Removed quartz cell for UV-Vis Spectrometer on north box

- Ordered replacement quartz cells

- Began heating salt for multicycle run in south box, sparged with chlorine to dry the salt

- Saw haze building up in north box and flowing throughout the line while waiting for Radiological Control Technicians

- Paused work, turned off the chlorine system, shut down the run

- Suspected chlorine leak through mass flow controller

- Revised MC and DOR procedures to use internal ball valves instead of mass flow controllers as isolation valves 
Pictures of Equipment/Gloveboxes After Haze Event

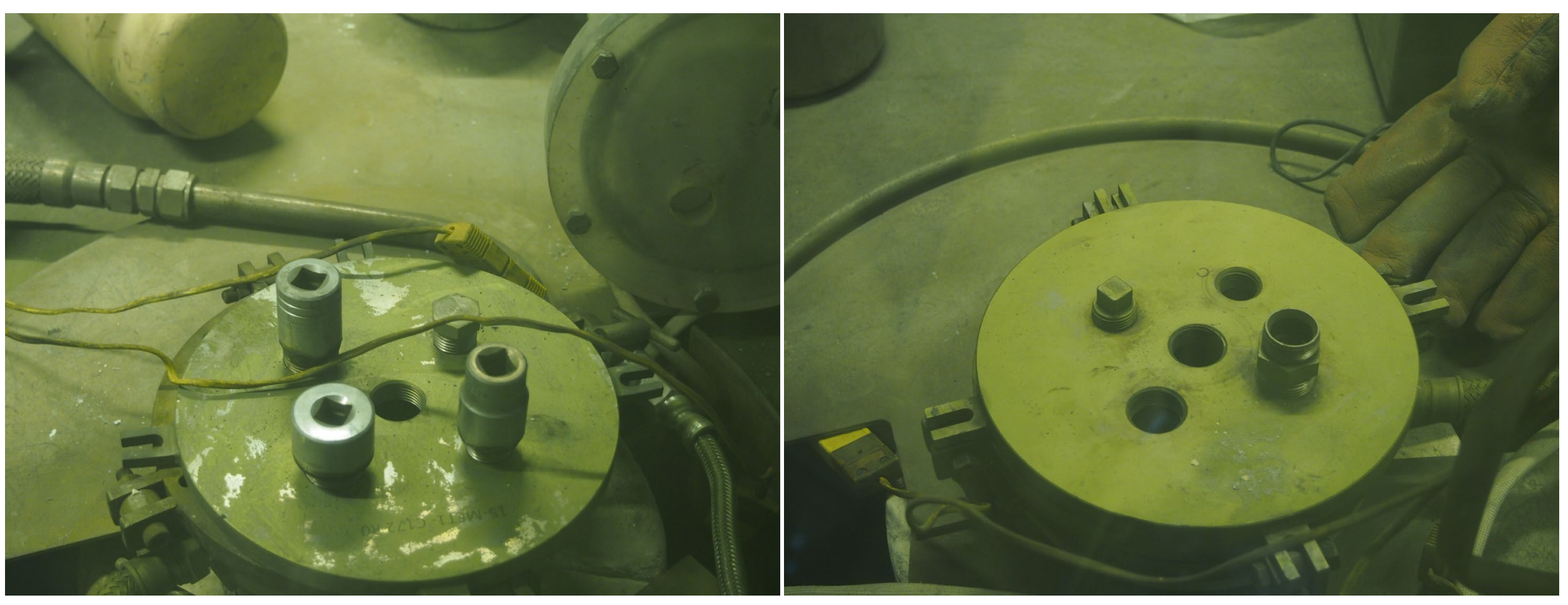




\section{Pictures of Equipment/Gloveboxes After Haze Event}

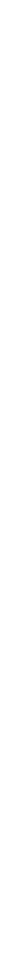




\section{Pictures of Equipment/Gloveboxes After Haze Event}




\section{Pictures of Equipment/Gloveboxes After Haze Event}




\section{Opening Metal Feed from Rocky Flats}

-Wrote new procedure to operate the Severmaster Can Opener

- Three 3013 cans have been opened

- Three engineers and one operator are trained to use the procedure

- Container board studying the container degradation

- SAFE-NMCA approved plan for processing:

- Measure items with cal/iso before introducing them into the glovebox line

- Cut one open at a time and split off any oxide

- Run the contents of each 3013 through Metal Chlorination as its own batch 


\section{Pictures of Severmaster Can Opening}
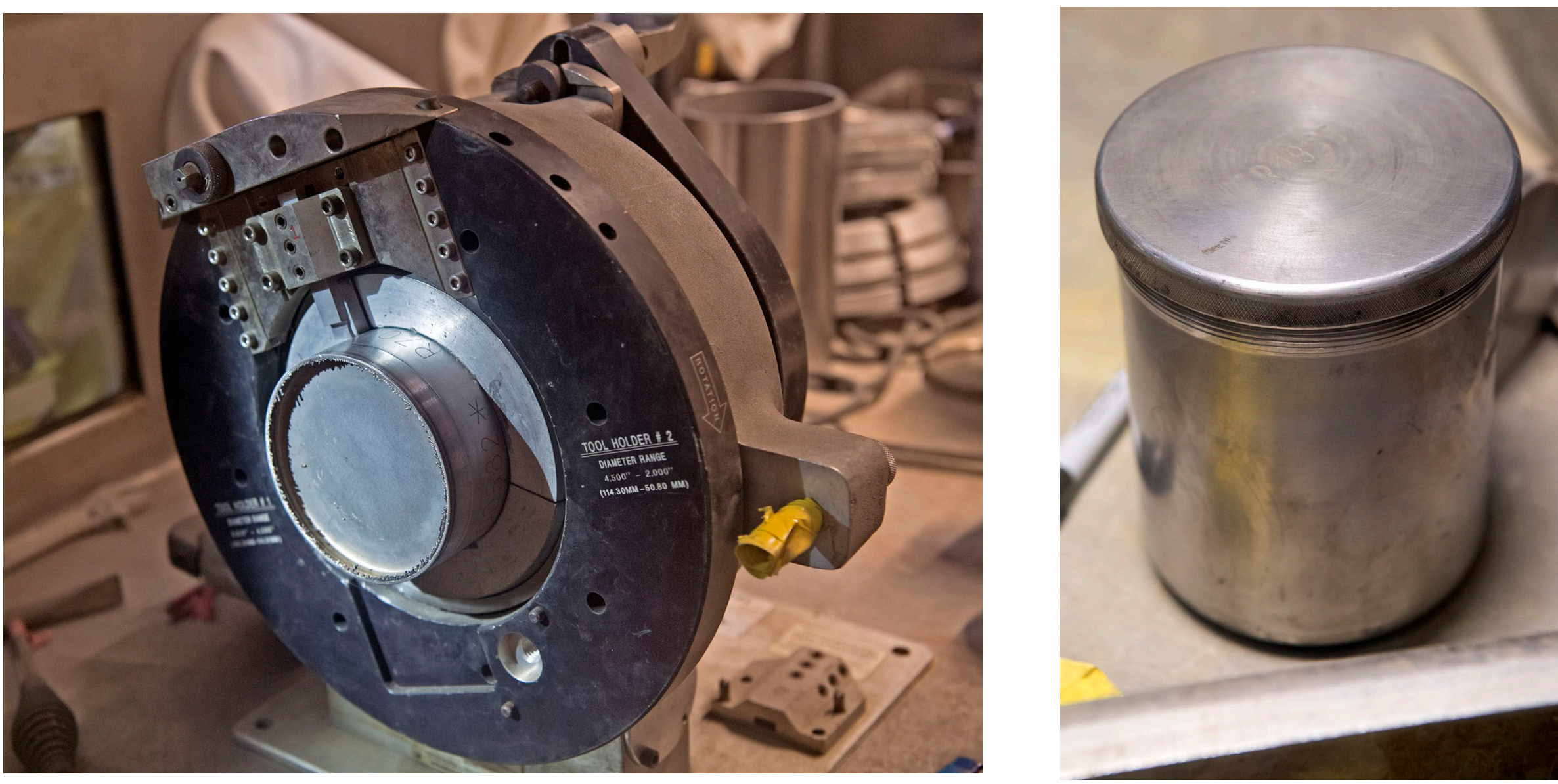


\section{Pictures of Severmaster Can Opening}
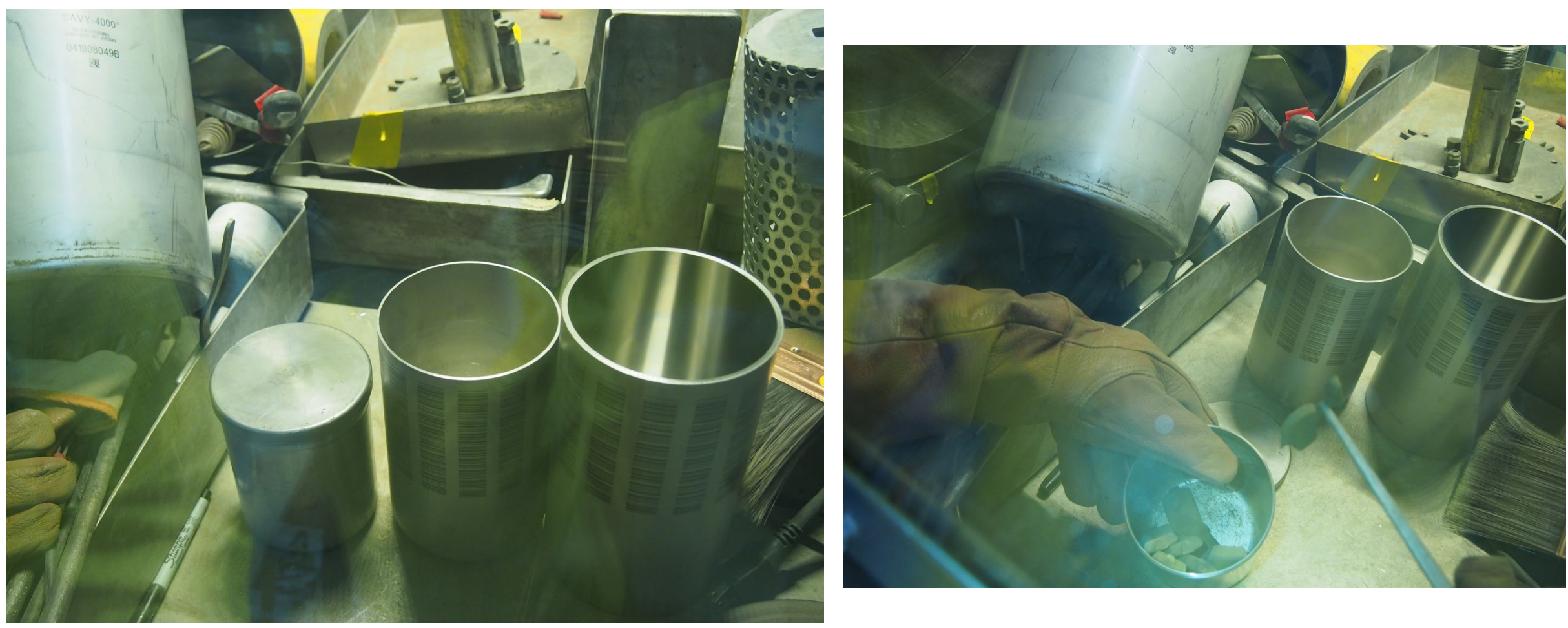


\section{Pictures of Severmaster Can Opening}

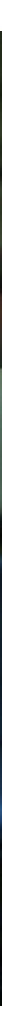




\section{Pictures of Severmaster Can Opening}

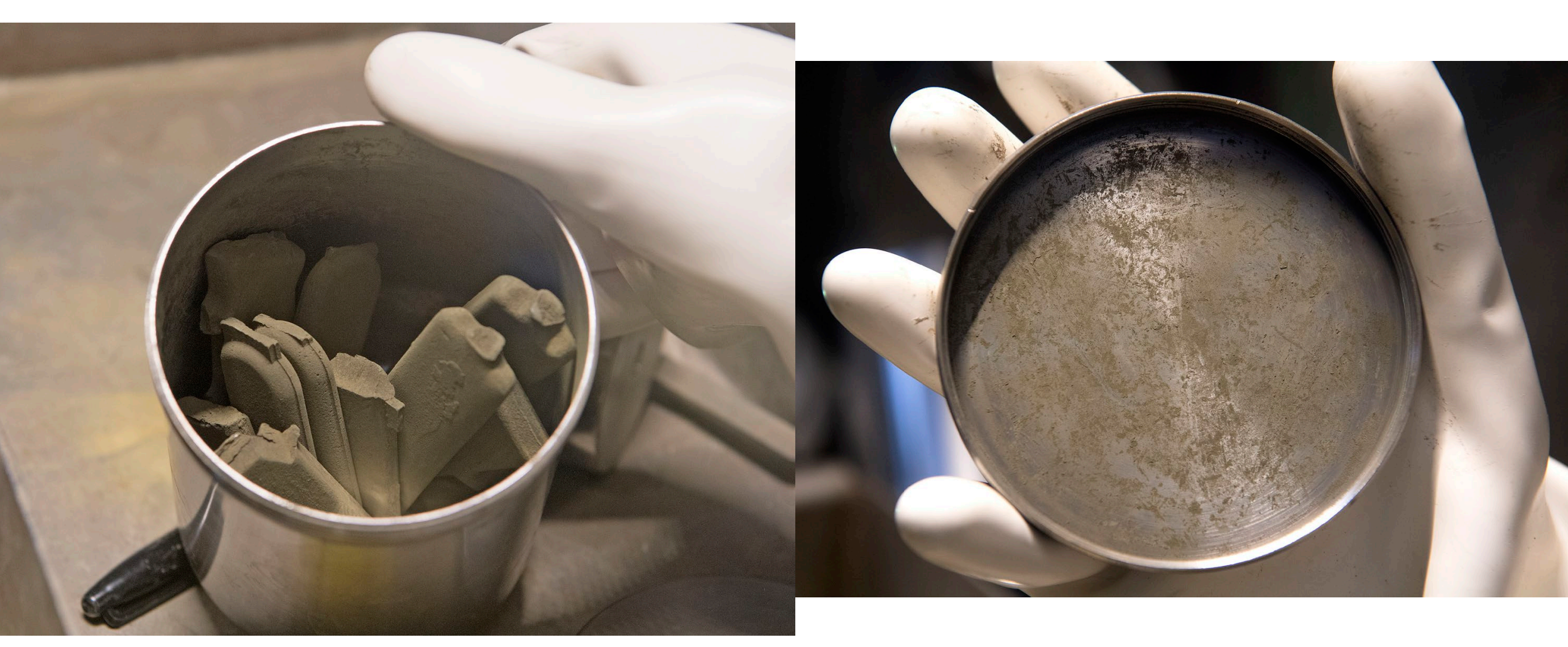




\section{Pictures of Severmaster Can Opening}

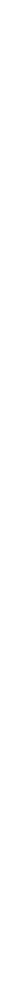




\section{Future Plans}

- Continue to receive metal from Savannah River/Rocky Flats and cut open cans to feed MC

- Separation factor studies on MC

- Calibrate the chlorine detection system with calibration gas generator - Allow for chlorine gas MC and multicycle DOR (MCDOR) runs

- In-line neutron counter for final NDA measurements

- Upgrade furnace controllers

- Continue to increase production:

- Averaging 2.8 runs per month to feed ER over the past 12 months (with MC and COL combined)

- FY20 pace planned for about 7 runs per month (2 per week for 40 production weeks). 


\section{Questions?}

